\title{
The Czech Economic Elite after Fifteen Years of Post-socialist Transformation*
}

\author{
PAVEL MACHONIN, MILAN TUČEK, MARTIN NEKOLA** \\ Institute of Sociology AS CR, Prague, \\ Centre for Social and Economic Strategies, Prague
}

\begin{abstract}
The East-Central European post-socialist transformations have now reached a new stage, with the need to address the problems of further modernisation and maintenance in the context of the EU. The role of elites in this process is as intermediators between the influence of the European context and the needs and interests of differentiated internal social structures. Their attitudes and behaviour exhibit a high degree of internal fragmentation and division corresponding to various strategical orientations favouring various societal models. The post-socialist Czech economic elite was initially reproduced out of former state socialist managers and their cadre reserves. After the first phase of economic developments, inspired by neo-liberal radical privatisation and elements of 'shock therapy', and once the new, more European phase ushered in many new factors, there was a distinct decline in the number of 'old-new' economic elite on the scene. In the empirical part of the article the results of several surveys are used to briefly describe the changes in the composition of the Czech economic elite in the 1994-2005 period and to summarise their attitudes and behaviour. The analysis concludes that the current image of a liberal and pro-European Czech elite is consistent with the stable and remarkable progress of the Czech economy since 1999, the considerable wealth, strong profits, and high salaries enjoyed by top elites, and the enhancement of their role in the European economy. There are also some limitations and weak points that diverge from this general picture. The article's conclusions touch on the question of the role of the economic elite in the progress of arriving at more consensual attitudes and behaviour among societal elites as a whole, favouring further economic growth, modernisation and the strengthening of social cohesion in the context of the EU.
\end{abstract} Keywords: post-socialist transformation, Czech Republic, economic elite, change Sociologický časopis/Czech Sociological Review, 2006, Vol. 42, No. 3: 537-556

\footnotetext{
* This article is part of a broader study dealing with the role of economic and political elites in the Czech post-socialist transformation. This study was prepared as part of the grant project No. A708283 of the Grant Agency of the Academy of Sciences of the Czech Republic 'Czech Elites on the Threshold of the EU'.

** Direct all correspondence to: machonin@tiscali.cz; milan.tucek@soc.cas.cz; nekola@centrum.cz
}

(C) Sociologický ústav AV ČR, Praha 2006 


\section{The post-socialist transformation and the role of the elites}

The East-Central European ${ }^{1}$ post-socialist transformations that occurred between 1989 and 2005 represent a new type of non-violent qualitative societal change. In view of the dissimilarity of the 'state socialist' social and political background of these countries in comparison with others, and owing to the new balance of power in the world and in European politics and economics, these transformations differ from most social and European political and social revolutions that have occurred before. The background of these countries was in a state socialist (totalitarian, egalitarian and non-market) system, with a largely industrially developed (semi-modern) but under-capitalised society, which in the post-socialist period progressed, with strong probability of success, towards democratic, market and the more or less meritocratic or class social systems characteristic of the early stages of post-industrial (late modern) society. This historical process has thus far gone through two phases, roughly determined by changing geo-political contexts. In the first phase (in approximately the first two-thirds of the 1990s) the transition to a democratic parliamentary political system took place alongside rapid and radical economic and social change, all of which occurred under the key influence of the dominant neoliberal stream in world politics and economics, and in many cases accompanied by the use of 'shock-therapy' or at least some elements of such an approach. ${ }^{2}$

The increasing economic difficulties and social tensions that ensued in the last third of the 1990s heralded the start of the second phase, which is still in progress, and which has been strongly influenced by: a) the requirements of the EU accession process, b) rapidly developing economic co-operation with advanced, mainly European countries, and c) the normatively set consequences of EU membership. This phase is characterised by the fact that the modernisation aspects of transformation typical for advanced European countries and the need to somehow strengthen social cohesion have moved to the forefront.

However, in individual countries one can nowadays observe phenomena indicative of a possible new turn to the more nationally oriented right, mainly as a result of some of the flaws and failures of left-centrist governments, including corruption, continuing economic and social difficulties, and a certain disillusionment

\footnotetext{
1 The category of East-Central European post-socialist countries roughly coincides with the new member countries of the EU from this region.

${ }^{2}$ In most of the European post-socialist countries the principles of the Washington Consensus II among leading world economic institutions were applied, though most of the governments in question preferred not to speak too loudly about it. Rapid liberalisation and the consequent privatisation of all decisive spheres of the economy, accompanied by 'shock therapy' were typical features of the economic reforms in most post-socialist societies. Among the specific aspects of the first phase of Czech economic reform was the stress laid on creating a domestic (national) economic elite and a middle class and the extreme rapidity of the changes, mainly enabled through the unorthodox method of combining the voucher and administrative methods of privatisation [cf. Mlčoch 1997; Sojka 2004].
} 
with developments in both world and European politics. This turn recently manifested itself in the outcome of the parliamentary elections in Poland in 2005 and to some extent also in the process of constituting a new government in the Czech Republic after the elections in June 2006.

However, this description of the two historical phases does not apply fully to all the countries in question. For example, the temporal pacing of Slovakia's course differs slightly from this general scheme, owing to a nationalist and populist episode in politics that detained the whole process for years. However, nationalist and populist tendencies also exist in other countries and may intervene in further stages of development. The changes in the Baltic republics have also shown some specificity. ${ }^{3}$ But the problems typical for each of the two basic phases had to be solved in all the countries of East-Central Europe, and only the future can tell whether the influence of several new factors and processes of differentiation will call into question the existence of a unitary East-Central European type of postsocialist transformation.

The current social and cultural-civilisational structures of the societies that experienced the type of changes characterised above can for the most part be described as a hybrid, consisting of the persistent bureaucratic and egalitarian relationships that survived from the past and the new meritocratic and class relationships. The young democratic systems are still just developing the requisite political culture and still trying to obtain a balance between administrative regulation and civil society. Moreover, the political party system seems far from achieving the relative stability that is typical of countries with a long history of parliamentary democracy. Only some professionals (mainly those active in the enterpreneurial sector of the economy) have attained economic and social statuses that correspond to their qualifications and achievements, while others (mainly those working in the public sphere) are still suffering from the consequences of inherited egalitarianism. This makes the influence of the new middle strata rather weak. At the same time, the clear contours of a new class structure have emerged. In addition to the gradual revival of a petty bourgeoisie class and a class of mid-level entrepreneurs and managers, a top managerial and a capital ownership class have also emerged (in many cases marked by the illegal and/or immoral way they attained their new positions), along with elements of a political and bureaucratic class, both of which enjoy some privileges. On the other hand, a significant unemployment rate and a considerable amount of poverty and other forms of social exclusion show that the top and bottom rungs of the social ladder have clearly become polarised. Such relationships

\footnotetext{
${ }^{3}$ The well-grounded empirical work by A. Steen [1997] shows that all three Baltic republics differ from the other Central-European type of post-socialist societies owing to their historical fate of having been much more closely tied to the Soviet totalitarian system. This also significantly influenced the composition and behaviour of even the post-socialist elites. In two of these societies - Estonia and Latvia - the conflict between elites representing ethnic majorities and those of the Russian population has had an extraodinarily strong impact on the behaviour of elites.
} 
form the social framework in which complex, deep and also controversial civilisational and cultural modernisation changes are taking place.

The complexity and continually changing nature of the external and internal circumstances surrounding the development of the post-socialist countries allows them the possibility to consider various social models. One such model resembles the neo-conservative and neo-liberal concept backed mainly (but not exclusively) by the present ruling strata in the United States. But there are also a variety of European types of social arrangements for consideration (e.g. democratic-socialist, social democratic, social liberal, christian conservative), all of which combine liberal and democratic concepts with some degree of respect for social rights and protection. Nor can the nationalist and populist models and even the Russian-type of centralist model be fully ruled out as yet. Conversely, a return to the principles of state socialism seems - at least among East-Central-European countries - very unlikely. And there is of course also the possibility that hybrid combinations of features from several of these models could emerge. ${ }^{4}$

In any case, the future of the post-socialist countries is in no way pre-determined, and there is still a broad field in which to make relatively free (both rational and irrational) choices. As EU membership provides some guarantees that these choices will be democratic in character, and the pre-agreed and codified rules of the game in this community lead the member countries towards modernisation and the maintenance of social cohesion, the manifold differences between future possible developments in most European post-socialist countries can be reduced to one main difference: between trends that strengthen the European Union and those that weaken it. This does not mean that the current state of the EU should be in any way idealised or that automatic support should be given to the bureaucratic and centralist tendencies that exist in this European organisation. However, the present situation, having originated in the course of European and world history, does not allow post-socialist countries in East-Central Europe any general choice today other than that of joining the advanced European countries and co-operating with them or opting not to do so.

According to the 'sandwich' concept, outlined by J. Pakulski in an elites workshop held in Prague several years ago, the role of national elites in the post-socialist transformation processes lies mainly in their intermediation of external (international) and internal (nationally specific) social influences and pressures, which are an expression of corresponding social needs and interests. However, the post-socialist

\footnotetext{
4 The statements in the preceding text are a condensed expression of broader reflections presented in the author's recently published new book [Machonin 2005b] devoted to the Czech historical experience and its relation to sociological thought. That work explains the post-socialist changes in East-Central Europe in terms of societal transformation instead of applying some version of the so-called transitological theories, particularly popular among some political scientists. Compare, for example, the systematic explanation of the application of transitological theory to the post-socialist changes in the work of one of the leading thinkers in this approach, Michel Dobry [2000].
} 
political elite are still more fragmented or even divided than they are consensually unified, and the attitudes and activities of the economic elite (also somewhat internally fragmented) have to respond to the possibility of substantial changes occurring in the composition of the power elites and their strategic orientations.

Each of the various internal components of a society's elites is bound to one or more international forces influencing the course of transformation. The majority of these forces are geopolitical in nature. The first such sphere of forces is represented by the combined influence of international economic institutions and international corporations, US capital and administration, and the international organisations controlled by them. These are usually referred to as the leading forces of globalisation. The second sphere is clearly the EU, with its broad network of economic, political, social and cultural institutions, and the advanced European economy. Although the interests of individual old EU members and their specific relationships to the post-socialist countries - both as a whole and individually - vary, the influence of the European community on the post-socialist societies has thus far been primarily relatively united. Despite the defeat of the Soviet block in the last stage of the Cold War, and despite the tensions that continue to exist between the successor states in the former Soviet Union and the other post-socialist countries, no one can deny Russia's continued political and military influence and its economic weight in some areas of international and European affairs. This makes the influence of Russia the third geopolitical sphere of influence, albeit a weaker one than the first two.

Individual segments of elites in the European post-socialist societies tend also to be tied to some internal social groupings, like classes, strata, ethnic groups, economic sectors, regions, settlement types, religious groups, and generations, etc. This is a result of tradition, ideology, and the social composition of the members and supporters of political parties or movements and their basic programme objectives. However, political subjects striving to occupy a leading position in the political system must to some degree transcend their ideological positions and traditional social anchoring in order to gain a broader than the traditional mass form of support, especially in times of relatively frequent political changes caused by unexpected phenomena. Such events can also occur in stable democratic systems, but in the rapidly developing post-socialist countries cases of this nature are far more common than in the advanced European countries. On the other hand, the at times confused political, economic and social developments in the European post-socialist countries have shown that for serious political subjects and their leaders it does not pay to deviate too much or too long from promoting the needs and interests of their social base of supporters or from their own traditions, ideology and past programmes.

Today, how fragmentated the political elites in the European post-socialist societies are varies considerably from one country to the next. Many factors in the structure and behaviour of elites co-determine for periods of varying length (depending, as a rule, on the election results) what kind of strategy is asserted in each country and has a chance to shape the societal systems either in favour of or against 
the complex transformation goals it entails. Such factors include, for example, the relationships between the individual segments of elites, the degree to which they cooperate, make compromises, lose or win, and compete or fight, and, of course, the strength of their influence on the population, as derived from both their programme strategy and tactical qualities and from the personal qualities of their leaders. For the time being, in most post-socialist countries the prevailing situation is that of a socially and politically divided 'ship that cannot sail': the principal social and political subjects exhibit only minimal ability and willingness to together search for and implement optimal or at least compromise solutions. This is one source of the sudden and at times almost haphazard changes that occur in the developmental trends in individual countries. While in such a situation the countries in question certainly need their elites as the mediators between the stimuli coming from Europe and the existing cultural and social handicaps experienced by the mass of society, and need them to perform their role of maintaining social cohesion to facilitate further modernisation, ${ }^{5}$ the model of elite behaviour probably ought to be more one of a rationally argued tendency towards promoting consensus, pragmatism, and compromise, and even a certain level of co-operation on important issues of European and national significance - something that Szomolányi [2002] calls the 'gradual convergence of elites'.

EU membership was assumed to be, and to some degree still is, one of the main unifying and stabilising factors assisting the progress of transformation. However, growing differences between individual member countries and various political streams within the EU in connection with the European Constitution and the interpretation of the Lisbon strategy have significantly weakened that effect.

\section{The origin, development and current structure of the economic elite in the Czech Republic}

A series of analyses of economic, historical and sociological data produced by a group of Czech sociologists in the years between 1994 and $2005^{6}$ indicate that the new economic elite were profoundly shaped by the composition, behaviour and attitudes of the majority of the state socialist management elite in Czechoslovakia and the Czech lands. It was Ivo Možný [1993] who put forth the idea that a large pro-

\footnotetext{
5 That is why we are wary of C. Lasch's [1995] severe criticism of the elites for their nearly total isolation from society and for their betrayal of democracy. In the current situation, the post-socialist elites are confronted with serious problems in some aspects similar to those that the elites of this region had to cope with during the period of nation-state formation. Therefore, neither we, nor the elites themselves, can afford to adopt a position of nihilist skepticism towards their role in society; instead we prefer rational and realistic criticism and a motivational emphasis on how they should perform their positive role.

${ }^{6}$ See Machonin [2005a], Machonin and Tuček [1994, 1996, 2000, 2002], Machonin, Tuček and Gatnar [1995], Hanley et al. [1996], Machonin, Št́astnová et al. [1996], Matějů [1997], Tuček
} 
portion of Czech managers had in the 1980s already become interested in making substantial changes to the Czech economic system. This means that they were aware of a) the weakness of the Czech economy in comparison with economies in more advanced countries, $b$ ) the disadvantages arising from their limited right to make decisions within a command economy, and that a role was played even by the fact that $c$ ) there were evident limits to their income in comparison with the salaries of western managers, not to mention the incomes and wealth of capital owners. In particular young and middle-aged, better-educated managers in mid-rank positions in the economic hierarchy, regardless of whether they were members of the Communist Party or not, were dissatisfied with their status and the prospects for obtaining higher positions occupied by old and faithful communist cadres.

\section{The historical phases in the development of the economic elite}

In the first phase of the transformation the large majority of the post-socalist economic elite - with the continued presence and active engagement of the non-discredited (and therefore less influential under state socialism but more so after 1989) part of the top and mid-level state socialist management - played a key role in the privatisation process and profited maximally from its prevailingly national character. According to the Elite Research $1994^{7}$ two-fifths of the economic elite in 1994 had also been members of the state socialist elites, though not necessarily in the same positions. We will call them the 'old-new economic elite'. As for the other three-fifths, which we will refer to as the 'new economic elite', in 1989 30\% occupied a position managing several departments in an enterprise or in some other organi-

[1996], and Tuček et al. [1997, 2005]. The common thread in this series of titles is the study of elites as a part of stratification and mobility research. Many of the ideas expressed in these studies, mostly written by P. Machonin and M. Tuček, or with their participation, are used in this article without special quotations. Something similar applies also to the reflections on some general concepts concerning the characteristics and roles of elites in the process of postsocialist transformation, as elaborated on the basis of work on elites conducted by an international team in the spirit of new 'elitism' and their application to post-socialist transformations formulated mainly by John Higley, J. Pakulski, G. Lengyel, W. Wesolowski and others. See, for example, Best and Becker [1997], Dogan and Higley [1998], Frentzel-Zagórska and Wasilewski [2000], Higley [1997], Higley and Lengyel [2000], Higley, Pakulski and Wesolowski [1998], and Steen [1997]. Most of the Czech and foreign works referred to are based on data on elites collected in the first half of the 1990s. This paper aims to grasp the results of the changes in the structure, attitudes and behaviour of elites in the second half of the 1990s and at the beginning of the 20th century. A cross-national comparison can be hoped for after the data from other European post-socialist countries is collected and elaborated.

7 The 'International Elite Research in the European Postsocialist Countries' in 1994 was led by I. Szelényi and D. Treiman, and in the Czech Republic by P. Matějů and M. Tuček. For details see Szelényi and Treiman [1991], Szelényi, Treiman and Wnuk-Lipiński [1995], Tuček [1996], Hanley et al. [1996] and Matějů [1997]. 
sational unit, which means that they were close to an elite position, while $55 \%$ were mid-level management, and only 15\% were 'real newcomers' to the management or capital-ownership structure after 1989 [Tuček 1996: 157-161].

These findings falsify the general validity of the hypothesis of elite circulation or qualitative exchange as one of the possible sources of new elites recruitment [see Szelényi and Treiman 1991; Szelényi 1995]. ${ }^{8}$ Exceptions to this falsification can be found only among new owners, who attained their position in the restitution process, and while this was a relatively more common occurrence in Czechoslovakia than in other post-socialist countries, only a limited number of restituents actually carried on in their or their parents enterpreneurial activities, and only a small number them became members of the real economic elite. Nor has the assumption that there was a tendency towards a kind of conversion of the old political capital into new economic capital been confirmed as a widely valid rule, though a number of such cases did indeed take place. In 1994 the proportion of former communists among the 'old economic elite' amounted to 95\%, among the old-new 83\%, and among the new 53\% [Tuček 1996: 157-161]. Data from a 1999 survey $^{9}$ indicate that these percentages had fallen to approximately $25 \%$ by the end of the 1990 s, while the age composition of the current elites strongly suggests that the decline is continuing. ${ }^{10}$

Serious economic and social difficulties and an increase in the level of popular dissatisfaction in the years 1995-1998; the apparent existence of many illegal and/or immoral activities among a not negligible part of the old/new and new economic elite; corresponding changes in the composition of the government (1997, 1998) and in economic and social strategy; a series of bankruptcies of privatised banks, big industrial enterprises and other big firms; the increasing inflow of foreign, particularly European, capital with corresponding personnel changes; the start of serious negotiations for EU membership; the gradual generational change in favour of younger and, in terms of education and/or fresh experience, better qualified cadres: all this, plus some other factors, ${ }^{11}$ led in the final years of the 20 th cen-

${ }^{8}$ Conversely, the hypothesis of nearly immediate qualitative exchange of at least the power elite was verified as one of the basic characteritics of the Velvet Revolution.

9 The survey on 'A Decade of Post-socialist Transformation in the Czech Republic' in 1999 was led by M. Tuček. For details see Tuček et al. [2003].

${ }_{10}$ That there was a relatively high percentage of former communists among the economic elites in 1994 does not mean that they were advocates of communist ideology. For most of them - especially the younger ones, but also the middle aged - membership in the Communist Party began during the 'normalisation' period and was the only way in which they could pursue a career. After November 1989 most of them quickly severed their ties with this party and adapted themselves to the new demands of the market erconomy.

${ }_{11}$ All these processes started gradually in the years 1995-1996. Their early stages have been described in the Czech report of the international business elite survey, which encompassed Poland, Hungary and the Czech Republic in 1997 and was led by Pál Tamás. See Tuček et al. [1997, 2005]. In qualitative interviews, twenty-three top managers active in the Czech economy evaluated the Czech economic privatisation process and other reform steps as necessary. 
tury to the downfall of an important part of the economic old/new elite recently discredited in the new environment of society. Along with the downfall of prominent right-wing politicians engaged in economic policy (or shortly thereafter) a significant portion of top managers and/or capital owners belonging to the old-new economic elite were forced out of their positions, ${ }^{12}$ despite the fact that the criminal nature of the privatisation activities some were engaged in could not in most cases be proved owing to the absence of relevant legislation at the time of these activities. ${ }^{13}$ However, the work of the police and the justice system gradually became more effective and helped foil several cases of fraudulent behaviour, this time mainly among the nouveaux riches that had emerged out of the privatisation process.

In the ensuing years, as managers aged, those politicians and managers who had been involved in the reform processes of the 1960s and assisted in implementing the economic strategy of Miloš Zeman's minority Social Democratic government were gradually excluded from economic activity. At the same time the rise of the successful privatisers continued. New possibilities for professional involvement in the economy opened up to people with political ties to the Social Democratic Party, and from 1998 to people with ties to the Civic Democratic Party, which gave the minority government limited support, and since 2002 also to those tied to the Social Democratic Party's coalition partners. Some privatisers even came to rank among the very top elite. The emphasis governments since 1998 have put on foreign capital investment soon brought about a new wave of recruitment of newcomers to the

On the other hand, they criticised the numerous economic policy mistakes made by the second Czech government under Václav Klaus. They did not of course mention the evident mistakes made by the top management of the firms they represented. Shortly after the interviews, some large Czech firms, whose top figures had been involved in the survey, collapsed, and most of them had to undergo substantial reorganisation, including changes in the ownership structure and corresponding personnel changes. This mainly occurred over the course of the three years after the data sampling, which took place in 1997, that is, the same year the second, unsuccessful government, headed by the main protagonist of neo-liberal reform in the Czech Republic, Václav Klaus, collapsed. Simultaneously, many prominent figures that backed neo-liberal economic policy, like economic ministers and the heads of privatisation institutions, disappeared from the top economic-political positions.

12 The series of bankruptcies of big both industrial and financial firms was accompanied by the departure of a group of influential post-communist managers or owners. In the list of the fifty richest Czechs (see below) none of their names can be found. The data on the decline in the proportion of former communists among managers cited above, and the data indicating a juvenilisation of the economic elite (see below) can be seen as indirect proof of the fact that an acceleration of the exchange of the old-new economic elite for the new new elite was not typical just among its wealthies members.

${ }_{13}$ The well-known and often criticised delay in the introduction of the relevant legal provisions only after the actual privatisation process - regardless of whether it was intentional or not - was one of the indispensable elements of the Czech neo-liberal privatisation strategy as well as the extreme speed at which privatisation occurred, as it allowed irreversible changes to be made before the population could become aware of their real nature. 
economic elite, partly from abroad, and in most cases from the ranks of the middleaged and younger domestic cadres (some of them graduates of professional study programmes in the Czech Republic or abroad).

\section{The fifty richest Czechs}

Some interesting information relating to this issue was provided in an overview of the fifty richest Czechs, which was published at the end of 2002 in the magazine supplement of one of the major national daily newspapers [Magazin Lidových novin 2002]. ${ }^{14}$ It is not surprising that this source indicated that there was only one woman on the list of the richest people. Further it showed that twenty-three of them were under the age of 40 (six of them in this age group were professional sportsmen approaching the end of their active career), fifteen were in the age group 40-49, and only ten were in the age group 50-59.

There were only two people from the oldest generation (60+) on this list, both of them restituents and at the same time dissidents. In addition to them there was also one relatively younger heir to a former family enterprise on the list. Only one (!) man on the list belonged to the old-new political elite and used his social and political capital to acquire a good deal of economic capital as a lawyer. One young man benefited his career by using his position in a fund dealing with the confiscated fortunes of the state socialist youth organisation. And four on the list had returned to Czechoslovakia after 1989 with some amount of disposable capital. If we add up all these cases it is clear that only a real minority were those who had used their (or their ancestors') previous capital for their new careers.

This means that the overwhelming majority of the current Czech top economic elite (managers and capital owners with other than Czech or Slovak nationality were not included in the overview) can be described as nouveaux riches. ${ }^{15}$ However, this does not mean that these and the many other people close to them in the highest ranking economic positions were involved in the phenomenon Ivan Szelényi et al. called 'making capitalism without capitalists' [Eyal, Szelényi and Townsley $1998,2003]$. In the process of liberalisation and privatisation, which took place dur-

\footnotetext{
${ }^{14}$ Many important facts are presented here in a somewhat unsystematic and more journalistic manner. They are elaborated in the text according to the current usage in content analyses.

15 This is also true to some degree for the economic elite as a whole. According to the survey on elites 2003/2004, which will be referred to below [Frič, Nekola and Prudký 2005], 79\% of the current economic elite situate the event that was decisive for their professional careers in the year 1989 or later, and a full $48 \%$ of them after 1989 . According to these statements the share of those who started their career before 1989 must to have declined to $21 \%$. This means that for among the current economic elites the link to the old economic elite or their cadre reserves, resulting from the reproduction processes that prevailed at the outset of the transformation, is no longer fully valid.
} 
ing the second half of the 1990s and the beginning of the new century, and under the continued functioning of old-new or new companies these people became real capitalists, functioning normally in both domestic and international markets, regardless of their rather heterogeneous career backgrounds, though somewhat limited in their activities by certain factors (which will be mentioned below). Leaving aside the athletes, most of whom in the future are likely only to become part of the business elite, there remain fourteen newcomers who started out mainly as mid-level managers in industry, construction, transport, commerce, and similar sectors, another twelve in the sector of banking, privatisation funds, stocks, betting shops, financial companies and the real estate business, two in foreign trade, one in agriculture, one in the spa business, two in the media and show business, two in state administration, and two as real self-made-men who started out at the bottom. But their current standing among the economic elite, the amounts of their disposable capital, and their forms of behaviour place them, and others with similar statuses, unquestionably at the core of the developing capitalist class. In this regard there are no detectable features that distinguish them from the capitalist classes in statu nascendi that developed, for example, in bourgeois or most national liberation revolutions.

In the Czech case, as in many other post-socialist transformations, the opportunities and significance of this group are limited by two factors. The first is the apparent hegemony of foreign capital, which is represented among the contemporary economic elites primarily (but not exclusively) by managers of Czech origin, whose economic influence, based not so much on their wealth as on their mandates from abroad, is probably even stronger than that of the richest Czech capital owners and managers. The second limitation to the class positions of top Czech businessmen is the considerable amount of state intervention, based on the 'rules of the game' as established by legislation that dates partly from a compromise inclusion of the Charter of Basic Rights and Liberties in the new Czech Constitution in 1992 and partly from the past decade and the two election victories of the Social Democrats. On the other hand, the position and influence of strong economic subjects has significantly increased in the past several years, and their interests are often asserted not only through the media but also by some pressure activity, lobbying, and in cases even by clientelism and corruption, problems which have not yet been adequately tackled by the state administration.

The increasing emphasis laid both objectively and subjectively on the competitive strength and the modernisation of the economy, together with growing impact of the EU on Czech economic legislation and policy, and the increasing influence of foreign capital in the national economy have accelerated the generational turnover and the changes in qualifications and the attitudes of the economic elite. 
A comparison between 1994 and 2003/2004

There are data for comparing the description of economic elites at two different points in time - in 1994 and in 2003/2004..$^{16}$ In two different surveys conducting in these years economic elites were selected from a list of large and prominent firms and a sample of their top representatives was created. The sample was created in both surveys in a similar manner, which makes a comparison possible. Leaving aside the question how fully representative any sample selection in any elite survey can be, the results obtained through both surveys roughly correspond to known historical facts and sociological data on the developments of society as a whole and of the Czech economy and polititical system in particular, and thus enabled the interpretations presented in this paper.

The first piece of information to come out of the comparison is that the proportion of males in the economic elite decreased from $90 \%$ in 1994 to $80 \%$ in 2003/2004. This corresponds to the known fact that there has been an increase in the amount of private economic activity among women. However, the educational and qualification potential of women is nowhere near being fully applied, and it may be expected that the above trend will progress.

Data on the age structure of the economic elite are also significant and interesting. Though the average age of the Czech economic elite remained nearly equal in both periods (at around 46 years of age), the table clearly shows the differences that developed over time. The economic elite in the first phase of transformation was dominated by middle-aged people, while younger members of the elite were just starting out and there were few of the oldest members owing to the departure of the discredeted part of the state socialist elite. The middle-aged elites of 1994 be-

Table 1. Age structure of the Czech economic elite, 1994 and 2003/2004

\begin{tabular}{llccccccr}
\hline Year & Type of elites & $60+$ & $55-59$ & $50-54$ & $45-49$ & $40-44$ & $35-39$ & -35 \\
\hline 1994 & Old-new + new & 6.4 & 11.1 & 21.1 & 22.3 & 17.9 & 12.3 & 8.9 \\
$2003 / 4$ & Contemporary & 12.8 & 14.0 & 10.5 & 12.8 & 16.3 & 18.5 & 15.1 \\
\hline
\end{tabular}

[Data 1994, 2003/4]

\footnotetext{
16 The data from 1994 come from the already mentioned Czech elite survey in 1994. The sample of the elites studied as a whole in this case involved 1509 respondents. For 2003/2004 we are grateful to CESES (Center for Strategic Studies, Faculty of Social Sciences, Charles University), and particularly to the project director Pavol Frič, for allowing us to use the data from a survey on elites, the results of which have been published in an official report [Frič, Nekola and Prudký 2005]. In this survey the total sample size was 826 respondents. The use of comparable data from the early and the later phases of the post-socialist transformation enables us to better characterise the dynamics of the development of the Czech economic elite.
} 
Table 2. Highest attained education of the Czech economic elite, 1994 and 2003/2004

\begin{tabular}{llccc}
\hline Year & Type of elite & Apprenticeship & Full secondary & $\begin{array}{c}\text { Tertiary or } \\
\text { post-graduate }\end{array}$ \\
\hline 1994 & Old & 2.4 & 22.6 & 75.0 \\
1994 & Old-new + new & 0.8 & 13.8 & 85.4 \\
$2003 / 4$ & Total & 0.7 & 17.3 & 82.0 \\
\hline
\end{tabular}

[Data 1994, 2003/4]

came old elites in 2004, and in the meantime the proportion of young people increased substantially (not so with the political elite, as young people harboured some mistrust towards the political system as a whole). The natural turnover of top businessmen became a regular pattern of change in the structure of the economic elite.

The educational structure of the economic elite in the course of the transformation can also be compared. In 1989 the system of 'working-class directors', typical of the 1950s, had already been fully done away with, but the influence of the political approach on the nomination of cadres (applied mainly in the political purges at the beginning of the 1970s and later on in the system of cadre recruitment until 1989) still resulted in an inadequate proportion of people with tertiary education and of course to the insufficient qualification (one-sided qualifications inadequate for the new conditions) of all managers. This had clearly improved by 1994. In the sample of representatives of selected large firms it is possible to observe only a slight decline in the percentage of tertiary educated by 2003/2004, a decline that is much more visible in a wider sample from 2004/2005, which also included managers and owners of mid-sized companies (see below). This kind of decline indicates the existence of some upward mobility among new capital owners and managers with lower education owing to the liberalisation of the labour-force market. This opened up opportunities for applying other qualifications, not necessarily tied to education, for example, enterpreneurial skills and/or a willingness to take risks. However, it involves other risks, connected with the professional competence of members of the elite.

\section{The qualitative in-depth survey}

The contemporary economic elite mostly share a (neo-)liberal ${ }^{17}$ outlook and support EU membership and its positive influence on the Czech economy. This inclination was revealed in a short qualitative (= not representative) in-depth survey of seven-

\footnotetext{
${ }_{17}$ A general liberal orientation seems quite certain. As for the neo-liberal (and neo-conservative) inclinations, stressing the principles of monetarism and state non-intervention, they
} 
teen members of the business elite and economic experts on the impact of the Czech Republic's accession to the EU had during the last quarter of 2004 and the beginning of 2005. ${ }^{18}$ These findings were later corroborated using a broader CESES sample in 2003/2004 (see below). The participants in this research also gave a highly positive evaluation of the results and various aspects of EU membership. The most frequent positive evaluations were given to the country's inclusion in a broad European economic, market-type space, the economic contributions from structural and other EU funds, the close co-operation with European firms and their investment activities in the Czech Republic, the growth of the Czech economy, the rise in exports, and the economy's competitive strength, a slight increase in wages and the standard of living, the broader assortment of goods and services, and the fact that the expected rapid rise in prices did not occur. All these anticipated or already partially achieved modernisation shifts were viewed as leading to an increase in the authority of the Czech Republic on the international stage and an increase in the country's attractiveness. At the same time, their responses also revealed some significant criticicism partly pertaining to EU policy and especially to the policy of the Czech government. ${ }^{19}$

\section{The economic elite in 2003/2004}

This picture is supplemented by information from data obtained in a broader survey by CESES in 2003/2004 [Frič, Nekola and Prudký 2005]. In this survey 21\% of respondents declared they had very strong feelings about belonging to Europe), $45 \%$ had strong feelings, $26 \%$ had only weak feelings, and $8 \%$ had no such feelings at all. (These feelings were significantly stronger among members of the cultural and political elites, and the difference may be due to the specific problems of competition from abroad and the EU's regulatory tendencies which primarily affect the economic elite.) The respondents also answered a question about the expected contributions of the Czech Republic to the EU: $27 \%$ see this contribution as lying in education, $18 \%$ in the creativity, skill and flexibility of the work force, $11 \%$ in culture and the intellectual sphere, 3\% in historical experience, $10 \%$ in strategic behaviour,

were prevalent in the qualitative in-depth survey, but less so in the CESES survey, where the respondents relatively often referred to a need for some state regulation.

${ }_{18}$ The in-depth survey was carried out by Petr Hartoš from the Institute of Sociology several months after the Czech Republic's accession to the EU. On the other hand, the two Czech coalition governments that operated over the course of this period were exceptionally weak and gradually lost support from both the public and even more so from professionals. Though the Czech economy was showing quite positive developments at that time, the trend was not that obvious and was not sufficiently stable. This situation certainly had an influence on the results of the survey in question.

19 A more detailed reproduction and analysis of the results of this in-depth survey is to be published by the Institute of Sociology AS CR in a volume of papers by Machonin, Tuček, Nekola and Hartoš [2006]. 
$9 \%$ in the quality of production and services, while $22 \%$ chose various other kinds of response. This does not sound like any overestimation of the possible role of Czech national business in the European economy. On the other hand, Czech elites on the whole (including both businesspeople and politicians, and also cultural and mass-media professionals) are sufficiently self-confident where their role in a national dimension is concerned: $80 \%$ of Czech elites are sure that they are capable of mobilising people to take an interest in achieving a better future, $60 \%$ of them think that the elites possess sufficient will to modernise the country. When asked about the internal features of the elites, they were more skeptical. This applies particularly to the business elite, $49 \%$ of whose members characterised Czech elites as primarily focused on defending and securing their own interests, while $42 \%$ admitted that the elites have their acquaintances and connections to thank for their positions, and a full $74 \%$ indicated that the elites are too closely bound to networks of acquaintances and mutual services. It is no surprise that even members of the economic elite - though not to the same degree as the political elite - expressed the opinion that there is growing tension between the elites and the population; $14 \%$ definitely agree with this statement and 39\% somewhat agree.

Some important information on the ideological outlooks of the business elite is provided by data on the differentiation of the business elite by their sympathies for the main political parties: $40 \%$ of its members declare support for the leading opposition right-wing Civic Democratic Party, and 6\% for the small right-wing coalition party the Freedom Union, while the Social Democrats received the support of only $11 \%$. The influence of the Christian Democratic Union and the Communists is quite marginal, and $30 \%$ of the business elite do not support any of the political subjects in the domestic political arena. This structure of political orientations reveals the business elite to be the most right-wing oriented segment of the elites, similar in this regard to only top media professionals. These results corroborate the fact that there is a prevailing liberal orientation among the Czech economic elite and add that it signifies prevailing support for right-wing political parties with a neo-liberal approach to solving the country's economic problems. There is also further evidence of the positive view the business elite take of the European Union: $56 \%$ of the sample of the business elite declared the European Union to be a highly important institution for further societal development. This percentage is significantly higher than it is among the other segments of the Czech elites.

\section{The survey on elites in 2004/2005}

Another data sample exists from a survey carried out at the Institute of Sociology of the Academy of Sciences of the Czech Republic at the end of 2004 and the start of $2005,{ }^{20}$ using a sample of 470 respondents selected from the Czech business elite. The sample was comprised of directors, deputy directors, or owners of enterprises

${ }^{20}$ The project was led by M. Tuček. 
with more than twenty employees, which corresponds with the de-concentration of the enterprise structure that occurred in the process of privatisation and transformation. The economic elite is therefore conceived in somwhat broader terms than in the surveys in 1994 and 2003/2004. For this reason in the new sample the proportion of tertiary educated was only $66 \%$ while in the data from 1994 it was $85.4 \%$ and from 2003/2004 82\%. Clearly, the results of this survey, characterising the sample as a whole, cannot be used in a comparison with the data from 1994 or 2003/2004 discussed above. In order to narrow the research field to a group with characteristics similar to the concept of business elite as described in this article, it was necessary to focus on one sub-sample of owners or managers heading several economic units or departments: $85 \%$ of this group were males, $75 \%$ tertiary educated, $74 \%$ working in professions corresponding to their educational field and level. They declared themselves as belonging to the upper-middle or upper strata of the population. Also, $75 \%$ of them are highly or somewhat interested in politics, 32\% identified their political orientation as left-wing or left-centrist, $20 \%$ as neutral, and $48 \%$ as right-centrist or right wing.

EU accession was evaluated as useful for their companies by $57 \%$ respondents and as neutral by $35 \%$. A full $75 \%$ evaluated foreign investments as positive for their enterprises. In addition, $82 \%$ thought that the economy has a significant influence on political sphere, and $76 \%$ acknowledged the influence of politics on economy. One-half of the respondents valued the effects of the government's economic policy on the economy, while $43 \%$ felt that government policy has no influence on economic activities. Only $40 \%$ thought that the business elite forms a more or less cohesive group, while the remaining $60 \%$ indicated minimal or no cohesion. This complementary information in principle corresponds with what we know from the other data sources. The slight difference in the proportion of people with tertiary education (7\% less than in the CESES survey) is probably a result of the presence of heads of mid-sized companies in the selected sub-sample. Nevertheless, among managers and owners in top positions in Czech companies there clearly appears to be a predominance of people with tertiary education.

\section{Conclusion}

The composition, situation and attitudes of the Czech business elite revealed through the set of data sources discussed in this article correspond to the stable and remarkable progress of the Czech economy since 1999, and to the remarkable wealth, strong profits, and high salaries of its top members and the enhancement of their role in the European economy. A genuine top business elite has emerged in the Czech Republic, one that in principle differs little from its Western counterparts. ${ }^{21}$ There is a problem in the fact that some of the economic elite do not have a tertiary

${ }^{21}$ Even the wave of newly exposed economic criminality and corruption cases seems to be distinctly influenced by the presence of large economic companies and conflicts between them. 
level of education and are for this or other reasons not adequately prepared for solving the difficult tasks connected with modernisation and European integration. Also, the fact that some entrepreneurs and managers attained their positions through questionable means makes them somewhat less reliable actors in the situation of actual 'rule of law'. Nor can one ignore the manifest clientelism and corrupt behaviour of some of the economic and political elites.

One of the most important preconditions for changes in the composition, attitudes and behaviour of the post-socialist economic (and also political) elite to correspond to the requirements of the new phase of developments is for the EU to recover somewhat from the shock it suffered after the French and Dutch 'no' votes on the European Constitution and from the conflict concerning the outlook for the financial budget. From both Western and East-Central European populations comes a warning: an excessively rapid and ill-prepared (i.e. the absence of dialogue with the people of all the countries in question) institutionalisation of the economic, social and political strategies of an expanded EU and the onset of the eventual changes they bring about can easily disturb the strategic balance between modernisation and social cohesion that has been managed thus far. If this balance is renewed and incorporated into EU policies, then conditions favourable to the solution of principally the same issue on the national level could arise, that is, the establishment of a constant balance between ongoing modernisation and an adapted social cohesion within individual countries.

The role of the elites in the Czech Republic towards achieving this type of strategy can be defined as: a) to support modernisation changes (coming mainly, but not exlusively, from the EU, and, particularly stimuli from the more advanced part of the EU) as much as possible and contribute in this way to strengthening Europe's competitive strength, and b) to put through the kind of economic, cultural and social reforms that are acceptable to the people as a contribution to the improvement of the standard of living and the culture of a broad strata of the population. Ongoing economic growth and relative progress in the process of modernisation in the Czech Republic since 1999 render the creation, application, and fulfilment of such a strategy a real possibility. But there are two significant obstacles to this. The first one (not discussed in detail in this article) is the internal structure and quality of the political elite in particular. The second (thus far more latent than manifest) is the tension between the current power elite and the more neo-liberally oriented economic elite, particularly the latter's top representatives at the head of large companies. Irregardless of the various possibilities for further political relationships within the country, the elites in Czech society can contribute to further adapting society to the new conditions and tasks arising from the country's membership in the EU if process could be achieved in strengthening consensus within its internal structure. ${ }^{22}$

\footnotetext{
${ }^{22}$ By consensualisation we mean real progress toward agreement (or at least toward realistic compromises) of the relevant segments of societal elites concerning not only a) the rules of the game of a democratic state of law (including the peaceful exchange of owners, managers,
} 
To this end it would be desirable to solve at least some portion of the many internal cleavages and conflicts that exist within the elites. The cleavages are not too sharp within the economic elite. Ongoing generation shifts and much more intensive support for research and development, education, the spread of information, international co-operation and counter-corruption measures should improve this aspect of the problem. Experience thus far suggests that even the problem of the economic elite having to adapt to changes in the power elite (e.g. after parliamentary elections) is not beyond a solution, on the condition of course that internal contradictions within the political elite are regulated to a socially acceptable degree. Some difficulties in the economy and in the social sphere can be caused by exclusive and biased practical adherence to the doctrine of maximum state non-intervention in economic and related or consequent social affairs, and, conversely, by the promoting equally biased radical populist strategies based on exaggerated state intervention.

This article was submitted to the editorial board of the Czech Sociological Review at the end of May 2006, one week before elections to the Chamber of Deputies of the Parliament of the Czech Republic. It will be very interesting to observe what changes the election results bring to the state of affairs analysed in the paper.

PAVEL MACHONIN is an emeritus senior reasercher of the Institute of Sociology in Prague. In his work in sociology since the beginning of the 1960s he has initiated, led and took part in many empirical surveys and published and edited a number of books and papers concerning social stratification and mobility in state socialist and post-socialist society, modernisation and social elites.

MiLAN TuČEK has been working at the Institute of Sociology in Prague since 1974 in the field of sociological and statistical methodology and empirical research. He is the head of the Department of Social Transformation at the Institute and chair of sociology at the Faculty of Social Science, Charles University in Prague. He has participated in and led a series of empirical surveys and published a number of books and papers concerning social structure and mobility and social elites in state socialist and post-socialist society.

MARTIN NEKOLA is a research fellow at the Centre for Social and Economic Strategies (CESES) at the Faculty of Social Science, Charles University in Prague. His research interests are in governance, political participation and the relationship between elites and the public.

politicians and high bureacrats according to both the functioning of the economy and election results), but also b) the willingness of them to seek for elaborating common long-run crucial societal strategies corresponding to national needs and interests. 


\section{References}

Best, H. and U. Becker (eds.) 1997. Elites in Transition. Elite Research in Central and Eastern Europe. Opladen: Leske \& Budrich.

Dobry, M. (ed.) 2000. Democratic and Capitalist Transitions in Eastern Europe. Lessons for the Social Sciences: 1-15.

Dogan, M. and J. Higley. 1998. Elites, Crises and the Origins of Regimes. Lanham, Boulder, New York, Oxford: Rowman \& Littlefield Publishers.

Eyal, G., I. Szelényi and E. Townsley. 1998. Making Capitalism Without Capitalists. The New Ruling Elites in Eastern Europe. London, New York: Verso.

Eyal, G., I. Szelényi and E. Townsley. 2003. 'On Irony. An Invitation to Neoclassical Sociology.' Thesis Eleven. Critical Theory and Historical Sociology 73: 5-41.

Frentzel-Zagórska, J. and J. Wasilewski. 2000. The Second Generation of Democratic Elites in Central and Eastern Europe. Warsaw: IPS PAS.

Frič, P., M. Nekola and L. Prudký. 2005. Elity a modernizace. (Elites and Modernisation) Prague: CESES, Studie No 1.

Hanley, E., P. Matějů, K. Vlachová and J. Krejčí. 1996. 'The Making of Post-Communist Elites in Eastern Europe'. Working Papers 96:3. Prague: Institute of Sociology.

Higley, J. 1997. Changing Rulers and Changing Rules of the Game: Elites after State Socialism. Paper presented at the BUES workshop in Budapest.

Higley, J. and G. Lengyel. 2000. Elites after State Socialism. Theories and Analysis. Lanham, Boulder, New York, Oxford: Rowman \& Littlefield Publishers.

Higley, J., J. Pakulski and W. Wesolowski. (eds.) 1998. Postcommunist Elites and Democracy in Eastern Europe. New York: Macmillan Press.

Lasch, C. 1995. The Revolt of Elites and the Betrayal of Democracy. New York, London: W. W. Norton and Company.

Machonin, P. 2005a. 'Neúčast ve volbách jako jeden z indikátorů sociální soudržnosti / nesoudržnosti a její širší souvislosti (se zvláštním zřetelem ke krajským volbám 2004)." (Non-Participation in Elections as One of the Indicators of Social Cohesion/NonCohesion with Special Respect to the Regional Elections 2004). Naše společnost 1: 15-24.

Machonin, P. 2005b. Česká společnost a sociologické poznání. Problémy společenské transformace a modernizace od poloviny šedesátých let 20. století do současnosti (Czech Society and Sociological Knowledge. Problems of Societal Transformation and Modernisation since the Mid-1960s to the Present). Prague: ISV nakladatelství.

Machonin, P. and M. Tuček. 1994. 'Structures et acteurs en République Tcheque depuis 1989.' 1989: une révolution sociale? Révue d'Études Comparatives Est-Ouest 25 (4): 79-109.

Machonin, P. and M. Tuček. 1996. 'La génesis de las nuevas elites en la República Checa.' Cuadernos del Este 18: 9-22.

Machonin, P. and M. Tuček. 2000. 'New Elites and Social Change.' Pp 25-47 in Elites after State Socialism. Theories and Analysis, edited by J. Higley and G. Lengyel. Lanham, Boulder, New York, Oxford: Rowman \& Littlefield Publishers.

Machonin, P. and M. Tuček. 2002. 'Zrod a další vývoj nových elit v České republice (od konce osmdesátých let 20. století do jara 2002).' Sociological Papers 02:1. Prague: Institute of Sociology.

Machonin, P., M. Tuček and L. Gatnar. 1995. 'Aktéři a strategie sociální transformace a modernizace.' (Actors and Strategies of Social Transformation and Modernisation) Data a fakta 7.

Machonin, P., M. Tuček, M. Nekola and P. Hartoš. 2006. 'České ekonomické a politické elity po 15 letech postsocialistické transformace' (Czech Economic and Political Elites after 15 Years of Transformation). Prague: Iso AS CzR. 
Machonin, P., P. Štastnová, A. Kroupa and A. Glasová. 1996. Strategie sociální transformace české společnosti a jejich úspěšnost v parlamentnich volbách 1996. (Strategies of the Social Transformation of Czech Society and Their Success in Parliamentary Elections 1996) Prague: SLON.

Magazin Lidových novin. 2002. '50 nejbohatších Čechů.' (The 50 Richest Czechs) Prague: 25. 10.

Matějů, P. 1997. 'Elite Research in the Czech Republic.' Pp. 61-76 in Elites in Transition. Elite Research in Central and Eastern Europe, edited by H. Best and U. Becker. Opladen: Leske \& Budrich.

Možný, I. 1993. 'An Attempt at a Non-Economic Explanation of the Present Full Employment in the Czech Republic.' Czech Sociological Review 1: 199-200.

Mlčoch, L. 1997. Zastřená vize ekonomické transformace. (The Veiled Vision of Economic Transformation) Prague: Karolinum.

Sojka, M. 2004. 'Czech Transformation Strategy and Its Economic Consquences: A Case of an Institutional Failure (or the Economic Consequences of Mr. Klaus)'. Pp. 109-128 in Democracy and Market Economics in Central and Eastern Europe: Are New Institutions Being Consolidated?, edited by T. Hayashi. Sapporo: University of Sapporo.

Steen, A. 1997. Between Past and Future: Elites, Democracy and the State in Post-Communist countries. A Comparison of Estonia, Latvia and Lithuania. Aldershot, Brookfield USA, Singapore, Sydney: Ashgate.

Szelényi, I. (ed.) 1995. 'Circulation vs. Reproduction of Elites during the Postcommunist Transformation of Eastern Europe.' Theory and Society 24 (5).

Szelényi, I. and D. Treiman. 1991. 'Vývoj sociální stratifikace a rekrutace elit ve východní Evropě po roce 1989.' (The Developments of Social Stratification and Recruitment of Elites in Eastern Europe after 1989) Sociologický časopis 27: 276-298.

Szelényi, I., D. Treiman and E. Wnuk-Lipiński. (eds.) 1995. Elity v Polsce, w Rosji i na Wegrzech. Wymiana czy reprodukcja? (Elites in Poland, Russia and Hungary. Exchange or Reproduction?) Warsaw: ISP PAN.

Szomolányi, S. 2002. 'Proces demokratizácie a graduálna konvergencia elít na Slovensku.' (The Process of Democratisation and the Gradual Convergence of Elites in Slovakia) Pp. 59-79 in Teoretická východiska a zkušenost výzkumu nových českých elit, edited by L. Gatnar. Prague: Sociologický ústav AV ČR.

Tuček, M. 1996. '4. Vytváření nové elity.' (4. Creation of the New Elite) Pp. 154-167 in Česká společnost $v$ transformaci. K proménám sociální struktury (Czech Society in Transformation. Metamorphoses of the Social Structure), edited by P. Machonin and M. Tuček. Prague: SLON.

Tuček, M., L. Konvička and P. Šimoník. 1997. Economic Elites in the Czech Republic. Formations and Strategies. Survey Report. Prague: STEM.

Tuček, M. (ed.) 2003. Dynamika české společnosti a osudy lidí na přelomu tisíciletí. (Dynamics of Czech Society and the Destinies of People at the Turn of the Millenium). Prague: SLON.

Tuček, M. (ed.) 2005. 'The Transformation of Economic Elites in the Czech Republic.' Pp. 99-137 in The Business Elites of East-Central Europe, edited by H. Steiner and P. Tamás. Berlin: Trafo Verlag. 